\title{
Manufacturing of Bioactive Peptides from Tomato Seeds to Isolate from Lactobacillus Plantarum Fermentation and Improvement of Antioxidant Activity
}

\author{
Marium Shehzadi*, Komal Malik, Nida Basher and Parvez Anwar \\ University of Gujrat Sialkot, Pakistan
}

Submission: December 1, 2017; Published: February 09, 2018

*Corresponding author: Marium Shehzadi, University of Gujrat Sialkot Sub-campus, University of Gujrat Sialkot Sub-campus Daska road Sialkot, Pakistan, Tel: 03225688750; Email: angeleye1996@yahoo.com

\begin{abstract}
The aim at the current study was to estimate the appropriateness at using protein-rich isolates from tomato seed like source of nutrition for the growth of lactic acid bacteria. Tomato seeds to contain rich source of proteins which has high nutritional value of the application of food technology. In this study, scientist examined the use of Lactobacillus plantarum strain to get high peptide values in fermentation process by using tomato seed meal separate as the substrate. Tomato seed meal has property of antioxidant activity which is very benefit of human against disease. The most advance techniques were used in this process like Gel filtration chromatography, HPLC analysis and FTIR analysis and PCR reaction. The result shows that Lactobacillus plantarum degraded and convert the tomato seeds into bioactive peptide which has ability to improve the antioxidant activity from isolating protein.
\end{abstract}

Keywords : Tomato seed isolate; Lactobacillus plantarum fermentation; Bioactive peptides; Antioxidant activity; FTIR.

Abbreviations : FTIR: Fourier Transform Infrared; AOAC: Association of Official Analytical Chemists; SDS-PAGE: Sodium Dodecyl SulphatePolyacrylamide Gel Electrophoresis; HPLC: High Performance Liquid Chromatography; DPPH: 1-diphenyl-2-picryl-hydrazyl free radical, ABTS: Azino-bis (3-ethylbenzthiazoline-6-sulfonic acid)

\section{Introduction}

Fruits, vegetables and other food processing produce a high rate of raw materials and waste materials like liquid which may be cause of the environmental pollution problems with loss of nutrients and valuable biomass [1]. At the present time, there is an ever-increasing demand of food engineers to reduce the rate of pollution problems and convert waste material into a useful by-product for other food industries. The other fact is that we all know health and nutrition are linked with each other. Food nutrients are able to activate the positive desirable physiological effect on the body which is benefit of human health [2].

The best example are tomato pomace, the unrefined material waste product of which, lingering after the juice mining process, consists of skins, seeds, and cores $[1,3]$. Fresh tomato has about $1 \%$ to $5 \%$ pomace which includes $60 \%$ of seeds and $40 \%$ of peel. Seed contains rich source of protein which is beneficial to health and the other $40 \%$ are raw material $[1,3]$. Tomato seeds contain high lipid contents such as linoleic acid and lycopene and in protein. Tomato seeds proteins have the mixture of compounds like globulin, albumin, prolamine, and gluteline components which have high nutritional values. Thus, these studies show that tomato seed proteins have high nutritional value which is benefit of human consumption. In addition, scientist has been reported that bioactive peptides derivatives from vegetable samples and it has antioxidant property including the soybean and chickpea seeds. But, the tomato protein seed has high nutritional values and also exhibit antioxidant property [1] (Figure 1).

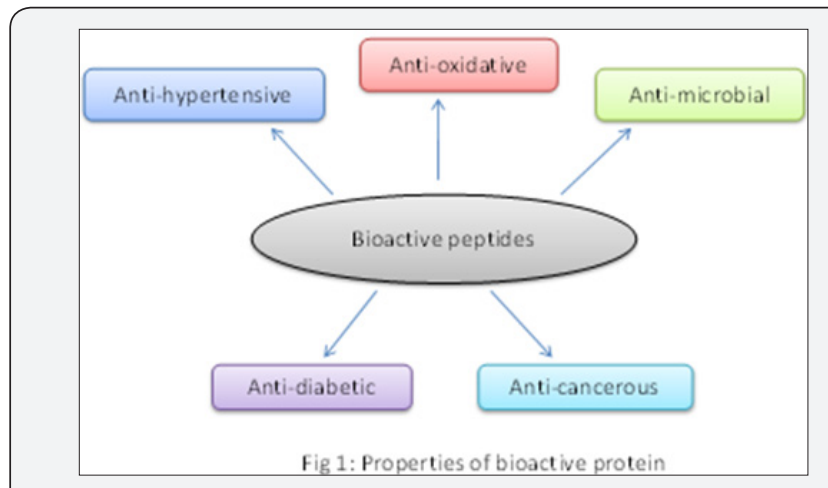

Figure 1: Properties of Bioactive Protein. 
Bioactive proteins are defined as protein hydrolysates the mixture of amino acid which commonly contain 10-20 amino acids joined with peptide bonds and have positive effect on the body functions. These physiological activities such as anti-hypertensive, anti-oxidative, antimicrobial, anti-diabetic and anti-cancerous depends upon amino acid composition, structure and in some parent protein molecules often have inactive bioactive proteins and can be produced by hydrolysis of different protein by using different techniques like

a) Proteolysis by enzymes from plants

b) Microbial fermentation of proteins by proteolytic microbes

c) Proteolysis by gastrointestinal enzymes.

In the past researches, microbial fermentation was used to releasing bioactive components in dairy product such as milk, meat, etc. microbial fermentation was the oldest technique which is widely used for preservation and food processing. However, Starter bacterial strain was used in fermentation process, lactic acid bacteria which has safest and have been used in beverage process or food process $[2,4]$ (Figure 2).

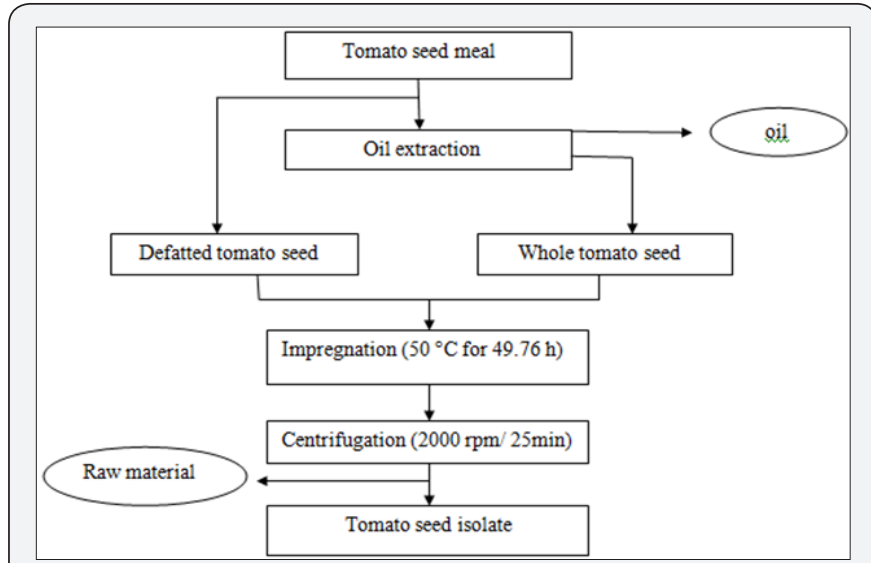

Figure 2 : Flowchart of protocol of tomato seed isolate extraction.

Lactobacillus plantarum a particular proteases, can hydrolyze the certain proteins and making multiple copies of different oligopeptides. At the present time, scientist has investigation into the new bioactive peptides that may be affecting the human physiological activities [3]. By using, bacterial hydrolysis of tomato seeds protein to convert the peptide hydrosylates into bioactive peptide through fermentation of defatted tomato seed waste material or raw material by Bacillus subtilis. But this fermentation has some drawbacks so scientist can be used fermentation based on hydrolysis protein of tomato seed by Lactobacillus plantarum. This method is simple and inexpensive to making bioactive peptides from tomato seed and also improved its antioxidant property. Next step was extracted protein analyzed by chromatographic techniques such as gel filtration, HPLC and identified by Fourier transform infrared (FTIR) spectroscopy [1-5].

\section{Methods}

Fermentation by lactobacillus plantarum was used to convert protein hydrosylates into bioactive peptides. Association of Official Analytical Chemists (AOAC) method is used to determine the crude protein concentration by the estimation of nitrogen. Gel filtration is used to analyze the aromatic polymers or high molecular weight protein in the tomato seed meal. SDS-PAGE (sodium dodecyl sulphatepolyacrylamide gel electrophoresis) was used to monitor the tomato seeds to isolate. Identification of free amino acid from tomato seed meal was evaluated by high performance liquid chromatography (HPLC) and Fourier transform infrared (FTIR) spectroscopy.

1,1-diphenyl-2-picryl-hydrazyl free radical (DPPH•) scavenging and 2, 2'-azino-bis(3-ethylbenzthiazoline-6sulfonic acid) (ABTS) was used to measure the antioxidant activity.

\section{Results}

In this experiment, result showed that after $24 \mathrm{hrs}$ of fermentation, isolated to extract from the radical scavenging activity was increased by $87 \%$. During fermentation, the rapidly increase in antioxidant activity is quality of the making of different bioactive peptides (Figure 3).

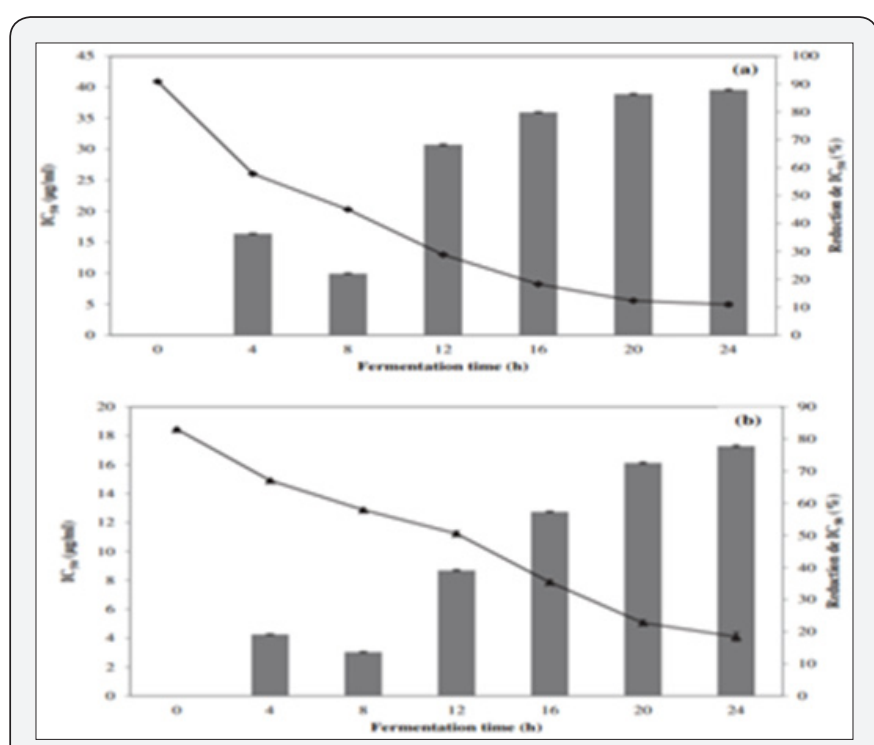

Figure 3

After $24 \mathrm{~h}$ fermentation, decrease to $18.44 \%$ and $68.99 \%$ were detected, correspondingly in crude and soluble protein content [3](Figure 4).

Gel filtration chromatography result showed the depolymerization of high molecular weight of the polymer and decrease to low molecular weight of monomer. The 
total number of amino acid decrease especially aspartic and glutamic acid is showed in HPLC analysis [3]

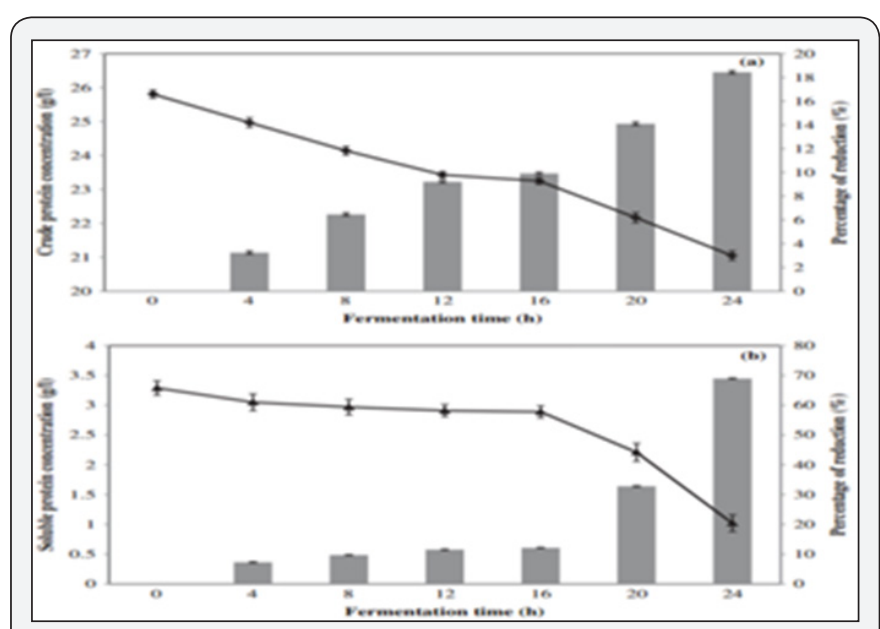

Figure 4

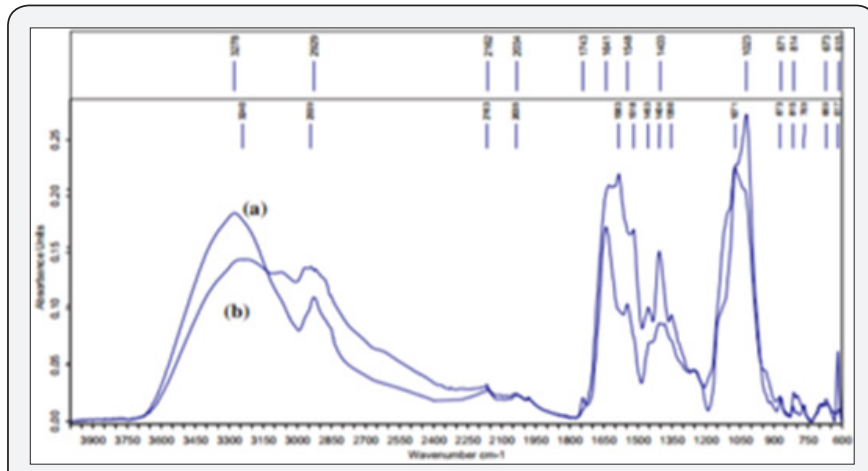

Figure 5
After $24 \mathrm{~h}$ fermentation, benefit of production of new aromatic and amide compounds was observed in FTIR [3] (Figure 5).

\section{Conclusion}

From the above discussion, bioactive protein is isolating from potato seeds were converted into antioxidant property after 24h Lactobacillus plantarum fermentation. Lactobacillus plantarum is non toxic to human consumption and give efficient result. Tomato seed protein has high value of nutritional factors and used for food preservatives [4,5].

\section{References}

1. Mechmeche M, Kachouri F, Chouabi M, Ksontini H, Setti K, et al. (2017) Optimization of Extraction Parameters of Protein Isolate from Tomato Seed Using Response Surface Methodology. Food Analytical Methods 10(3): 809-819.

2. Mechmeche M, Kachouri F, Ksontini H, Hamdi M (2017) Production of bioactive peptides from tomato seed isolate by Lactobacillus plantarum fermentation and enhancement of antioxidant activity. Food Biotechnology 31(2): 94-113.

3. Mechmeche M, Kachouri F, Yaghlane HB, Ksontini H, Setti K, et al. (2017) Kinetic analysis and mathematical modeling of growth parameters of Lactobacillus plantarum in protein-rich isolates from tomato seed. Food Sci Technol Int 23(2): 128-141.

4. Adeyemo S, Onilude A (2014) Molecular identification of Lactobacillus plantarum isolated from fermenting cereals. International Journal of Biotechnology and Molecular Biology Research 5(6): 59-67.

5. Torbica A, Belović M, Mastilović J, Kevrešan Ž, Pestorić, et al. (2016) Nutritional, rheological, and sensory evaluation of tomato ketchup with increased content of natural fibres made from fresh tomato pomace. Food and Bioproducts Processing 98: 299-309.

\section{Your next submission with Juniper Publishers will reach you the below assets}

- Quality Editorial service

- Swift Peer Review

- Reprints availability

- E-prints Service

- Manuscript Podcast for convenient understanding

- Global attainment for your research

- Manuscript accessibility in different formats

( Pdf, E-pub, Full Text, Audio)

- Unceasing customer service

Track the below URL for one-step submission https://juniperpublishers.com/online-submission.php 